\title{
MAPKAPK5 Gene
}

National Cancer Institute

\section{Source}

National Cancer Institute. MAPKAPK5 Gene. NCI Thesaurus. Code C113081.

This gene is involved in protein phosphorylation, mTORC1-mediated signaling and tumor suppression. 